\title{
Recent foraminifera from inter-reef channels, nearshore North Rarotonga, Cook Islands, South Pacific
}

\author{
G .W. HUGHES \\ Saudi Arabian Oil Company, Geological Research and Development Division, Exploration Department, P.O. Box 5000, \\ Dhahran, Saudi Arabia
}

\begin{abstract}
The Avatiu and Avarua sand-covered channels within the fringing reef of north Rarotonga, Cook Islands, contain foraminiferal assemblages considered to bc predominantly derived from the adjacent. reef platform. Benthonic species which display a depth restriction include Melonis affinis, Cassidulina delicata, Clavulina pacifica and Bolivina alata. Small (less than $200 \mu \mathrm{m}$ ), rare planktonic species, including Globigerina bulloides, are recovered from sediments as shallow as $8 \mathrm{~m}$, but an increase in species diversity and abundance is noted at $30 \mathrm{~m}$ in Avarua channel and $48 \mathrm{~m}$ in Avatiu channel.

No clear depth, substrate nor symbiont-associated restriction of species is evident, and this may result from mixing of primary microfaunal assemblages by sediment transport in this exposed part of the island. J. Micropalaeontol. 14(1): 29-36, April 1995.
\end{abstract}

\section{INTRODUCTION}

This study is based upon samples collected from the sediment-covered inter-reef channels adjacent to Avarua and Avatiu villages off the north coast of Rarotonga, the largest of the Cook Islands, in the South Pacific (Fig. 1). The samples were not specifically collected for foraminiferal study.

The island of Rarotonga is a deeply dissected cone of Pleistocene volcanic rocks which is surrounded by a low, raised Pleistocene coral platform up to $1.0 \mathrm{~km}$ wide. The fringing reef, which almost completely surrounds the island, varies from a minimum width of $100 \mathrm{~m}$ on the northern side to a maximum of nearly $1 \mathrm{~km}$ on the southern side and is interrupted by a number of sand-covered channels, the largest of which form Avarua and Avatiu harbours. These channels extend seawards to depths of several hundred metres (Lewis et al., 1982) and were formed during times of relatively lower sea levels, when they were probably cut by rivers.

The Cook Islands lie within the hurricane belt and are influenced by the prevailing trade winds, from the east-south-east. During the hurricane season (November to March) humidity is high. The mean annual temperature on Rarotonga is $24^{\circ} \mathrm{C}$, and the average rainfall $2000 \mathrm{~mm}$ (Keating, 1978). A westerly current influences sediment transport, resulting from the tradle wind influence. Water clarity is very high as the ocean currents carry sea water from the open marine Pacific. Rivers draining Rarotonga are small, typically less than $4 \mathrm{~km}$ in length, and are predominantly clear as they drain an island consisting of Pliocene to Pleistocene volcanic rocks.

This study is primarily of a biogeographic aspect, as no other detailed record of foraminifera has been made from the Cook Islands. It was conducted in order to provide semi-quantitative documentation of the foraminiferal population of this part of the South Pacific.
In general, the foraminiferal assemblages resemble those described from other Western Pacific islands, but it is concluded that modification of the Cook Island assemblages results from greater open marine influence; many common Indo-Pacific reef-dwelling species were not found.

\section{MATERIALS AND METHODS}

Samples for this study were collected during 1980 by the Commission for the Coordination for Offshore Prospecting in the South Pacific (CCOP/SOPAC) in response to a World Health Organisation request to aid in the engineering design of a pipeline for sewerage outfall. As a consequence, the samples do not provide the most representative distribution for foraminiferal ecology, but nevertheless represent the only samples ever collected from the Cook Islands.

The Cook Islands Government tug, Avatiu, was used for surface sediment sampling, using a Shipek sampler. Sample localities were positioned using simultaneous measurement from shore stations using a Del Norte Trisponder Radio Positioning system. Water depths in the range $0-30 \mathrm{~m}$ were determined using a Ratheon DE-719 echo sounder. Depths exceeding $30 \mathrm{~m}$ were taken from the seismic profiling records. Areas of coral outcrop were differentiated from sand-floored sea bed areas using a Klein model SA-351A Sidescan sonar transceiver system in conjunction with an EPC 3200 dual channel graphic recorder.

Eleven samples were examined from the Avatiu area (Fig. 2, Table 1), from depths of $8-65 \mathrm{~m}$ and fourteen samples from the Avarua area (Fig. 3, Table 2), from depths of $8-120 \mathrm{~m}$.

Offshore Avatiu, the channel surface sediments are mainly fine to medium sand down to the $11 \mathrm{~m}$ contour, medium to very coarse slight and dark 'pepper and salt' coloured sand to $25 \mathrm{~m}$, and silty, fine to coarse, brown sand 


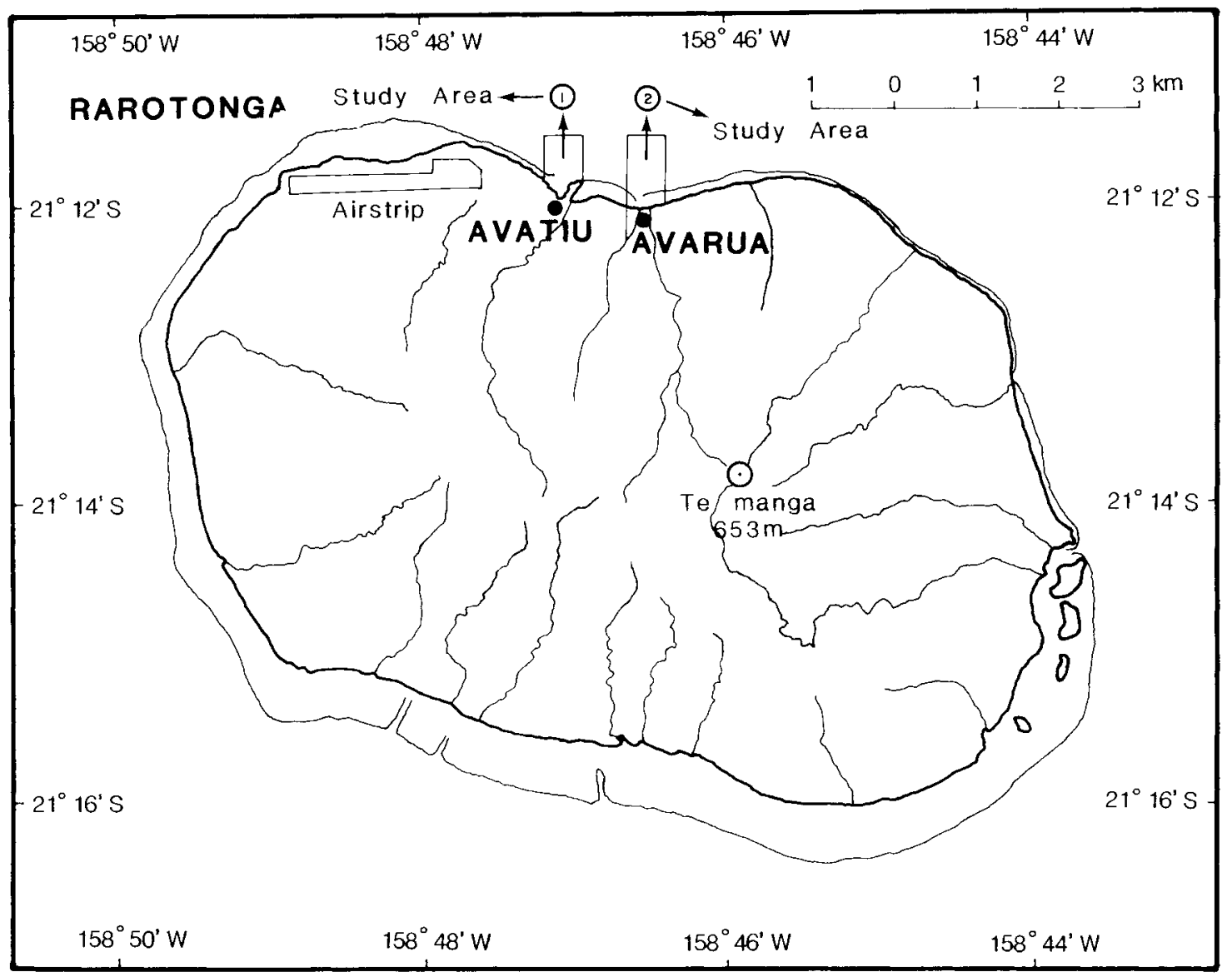

Fig. 1. Rarotonga Island showing coastline, main drainage, extent of fringing reef and location of study areas offshore Avatiu and Avarua villages.

seawards of the $25 \mathrm{~m}$ contour. The generally smooth, sandy channel floor is in places interruped by patch and pinnacle reefs $2-5 \mathrm{~m}$ in height and up to $25 \mathrm{~m}$ across, at least as deep as the $30 \mathrm{~m}$ contour. In the areas of coral rock, the small scale relief is between 2 and $3 \mathrm{~m}$.

Offshore to the narrow harbour entrance of Avarua, situated in a break in the fringing reef where the water depth is between 6 and $10 \mathrm{~m}$, the sea bed gradually descends to $20 \mathrm{~m}$. Channel surface sediments offshore to the narrow harbour entrance of Avarua, consist predominantly of fine to medium 'pepper and salt' sand. Between 30 and $60 \mathrm{~m}$, brown silt occurs within fine to medium sand. Seawards of $20 \mathrm{~m}$, some coarse and very coarse sand is present, particularly on the east side of the channel. This is possibly as a result of transport associated with the west-flowing trade wind-generated current which would transport fringing reef material into the channel.

Only random cuts of unwashed samples were made available for foraminiferal analysis and as the samples were not preserved, none were dyed for recognition of living specimens. Splits of the original cuts were washed over a 200 mesh sieve and the foraminifera picked. No photography of the specimens was undertaken because all species are well illustrated in the references cited.

\section{FORAMINIFERAL DISTRIBUTION}

Tables 1 and 2 display the sample numbers, water depths and dried sample weights, distribution and relative abundance of foraminiferal species recorded from samples arranged in order of increasing depth from Avatiu and Avarua channels respectively.

In Avatiu and Avarua channels there is a noteworthy consistency in the presence of foraminifera at all, or most, of the samples examined, the principal components comprising Cymbaloporetta bradyi, Borelis schlumbergeri, Heterostegina depressa, Peneroplis pertusus, Planorbulinella larvata, Siphogenerina raphanus, Sorites marginalis, Reussella simplex, Spirillina vivipara, Rosalina globularis, Amphistegina radiata and Planispirinella exigua. Small unornamented miliolids are common in all samples.

The rather unusual form Buliminoides williamsonianus was recovered from depths of $8.5 \mathrm{~m}$ and $30 \mathrm{~m}$ at Avarua channel. The restriction of certain species to deeper samples at both Avatiu and Avarua channels may indicate a depth restricted habitat, either within the channel or possibly upon the deeper part of the fringing reef which flanks the channels. Species which display such a depth restriction at Avatiu channel include Lenticulina $c f$. orbicularis $(12 \mathrm{~m})$; Cassidulina delicata, Bolivina alata, Bulimina simplex and 


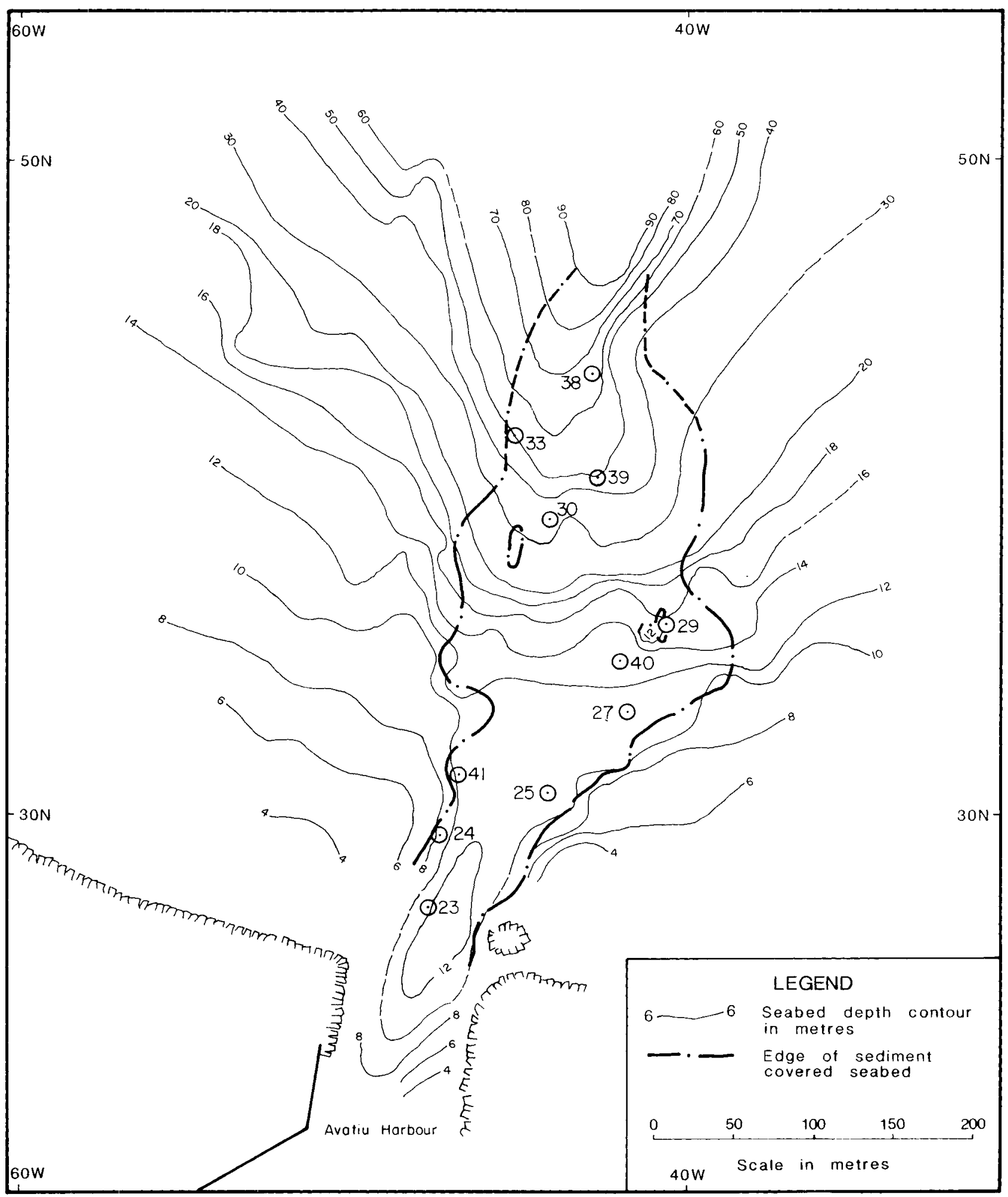

Fig. 2. Offshore Avatiu showing bathymetry, samples localities and channel boundary (Study Area 1). 


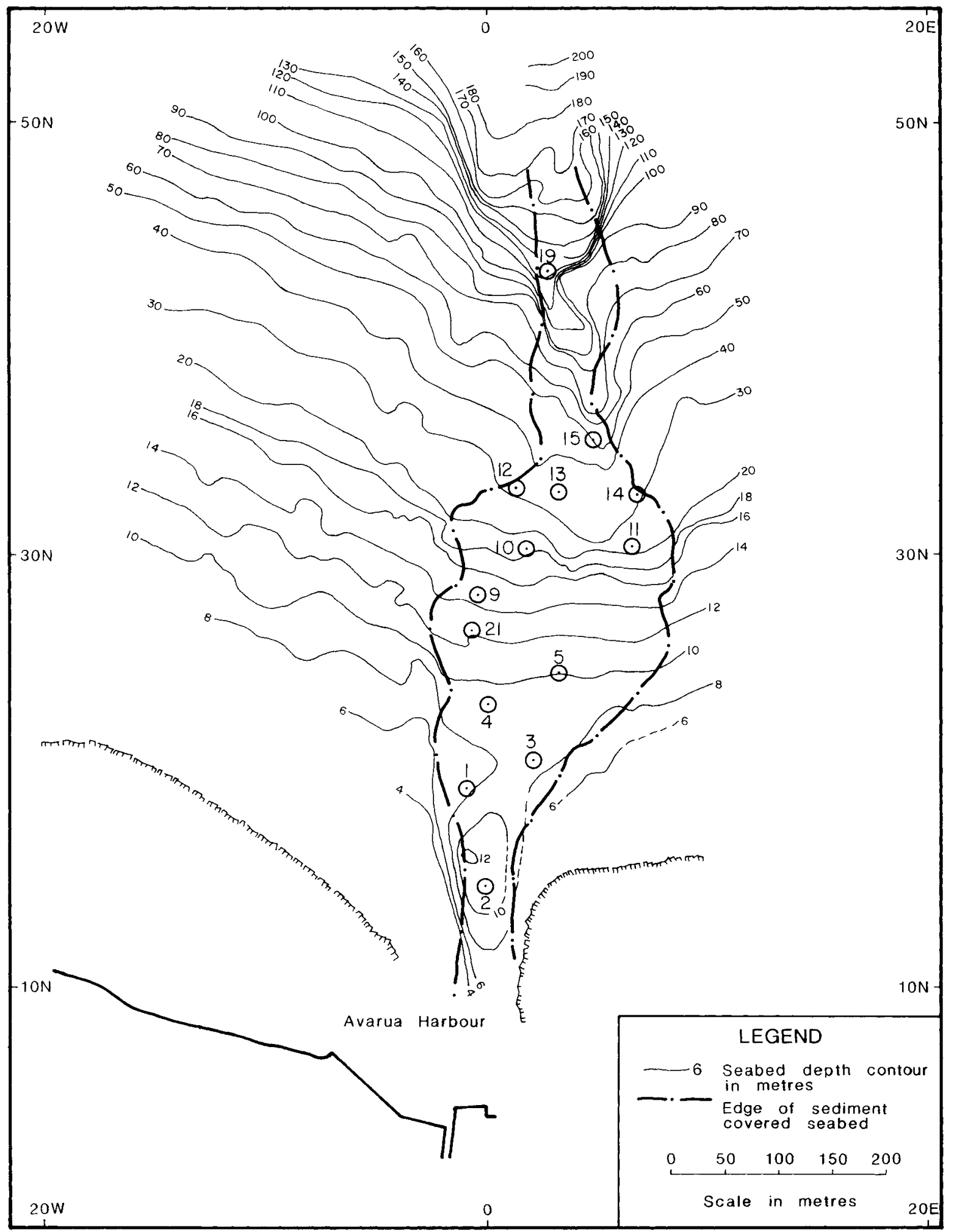

Fig. 3. Offshore Avarua showing bathymetry, sample localities and channel boundary (Study Area 2). 

Table 1. Foraminiferal distribution in samples from offshore Avatiu (see Fig. 2 for sample localities). Samples arranged in order of
increasing depth.

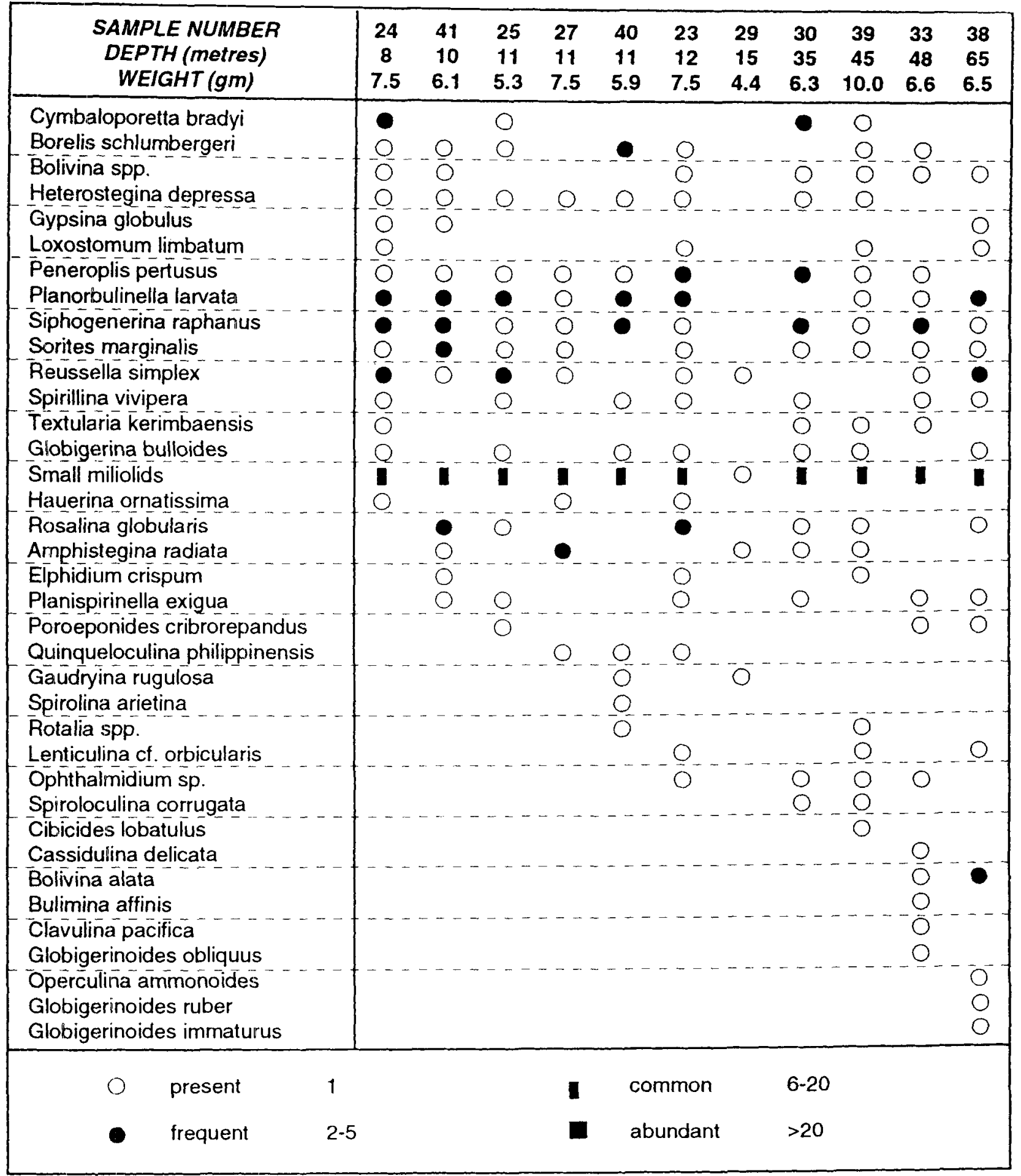

Clavulina pacifica $(48 \mathrm{~m})$; and Operculina ammonoides $(65 \mathrm{~m})$. In Avarua channel, certain depth-restricted forms include Bolivina hantkeniana and Bolivina porrecta $(20 \mathrm{~m})$, Melonis affinis $(33 \mathrm{~m})$, Cassidulina delicata $(35 \mathrm{~m})$ and Bolivina alata $(120 \mathrm{~m})$.
A few species are restricted in frequent or greater abundance to shallow habitats. Borelis schlumbergeri, for example, is not found below $15 \mathrm{~m}$.

The presence of planktonic species is often used to conclude the degree of open marine influence and it is of 
Table 2. Foraminiferal distribution in samples from offshore Avarua Harbour (see Fig. 3 for sample localities). Samples arranged in order of increasing depth.

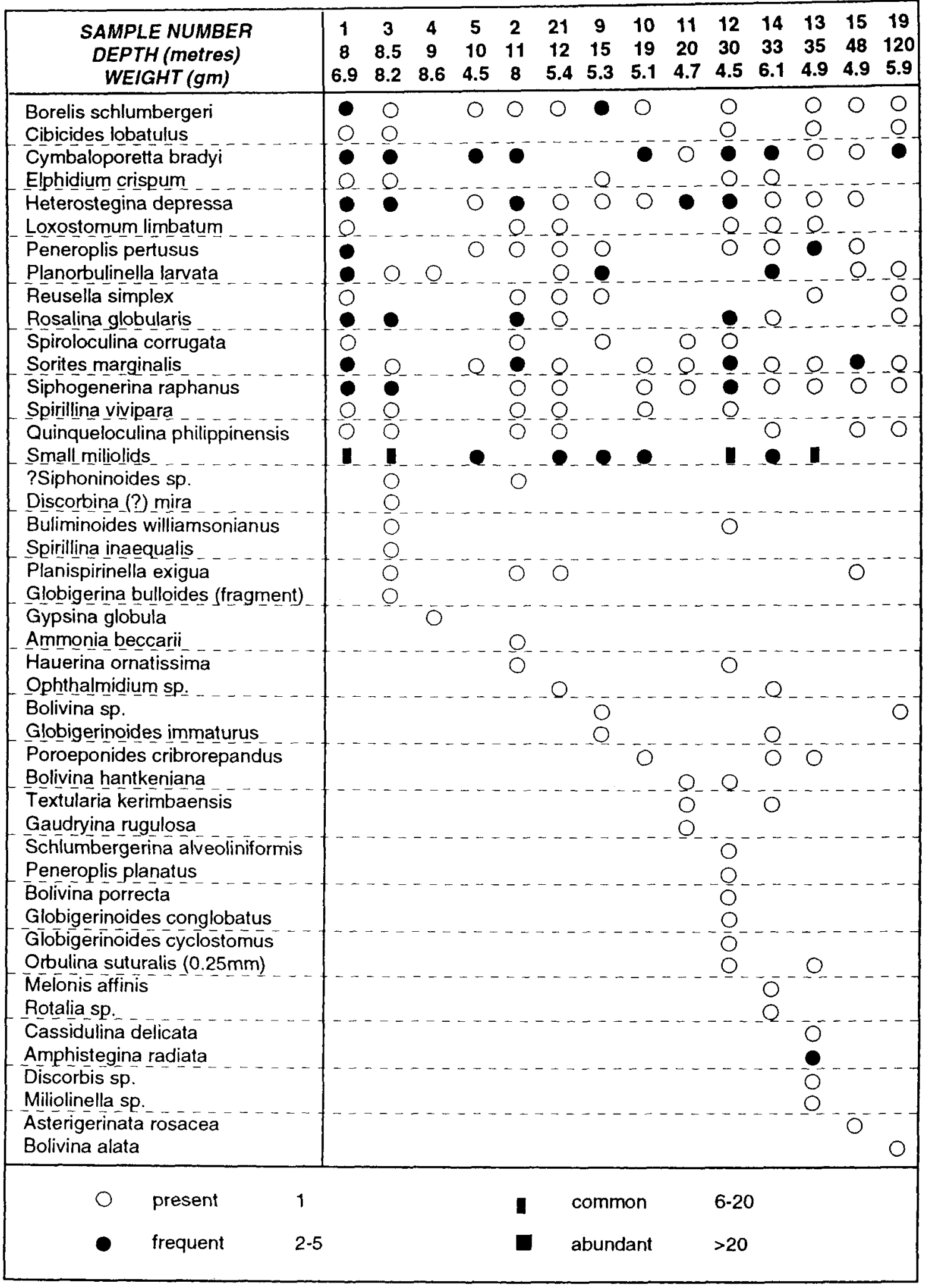


interest to note their distribution within the study areas. All planktonic species encountered measure less than $0.2 \mathrm{~mm}$ across, and this alone is of useful environmental significance. Globigerina bulloides is present in most samples deeper than $8 \mathrm{~m}$ at Avatiu, but only a fragment was recovered at $8.5 \mathrm{~m}$ at Avarua. At $15 \mathrm{~m}$ in Avarua, Globigerinoides immaturus was recovered, with two specimens recovered at $33 \mathrm{~m}$. A marked diversity increase in planktonic species is evident at $30 \mathrm{~m}$ in Avarua channel, and include Globigerinoides conglobatus, Globigerinoides cyclostomus and Orbulina suturalis. At Avatiu channel, planktonic species display an increase in diversity below $48 \mathrm{~m}$, manifest by the appearance of Globigerinoides obliquus, and at $65 \mathrm{~m}$ by the presence of Globigerinoides ruber and Globigerinoides immaturus. This apparent trend may, of course, represent the result of differential preservation; more turbulent shallow conditions possibly destroying the delicate planktonic tests.

Upon more detailed examination of Tables 1 and 2, the inconsistent difference of maximum depth range of certain species leads one to suspect that downslope transport has destroyed any real depth stratification of the species recorded. Such transport should be expected in exposed open ocean sites such as the study area, with mechanisms such as tidal surge and occasional cyclones being obvious candidates. These agents of either penecontemporaneous, or post mortem, microfaunal transport may explain the localized, anomalous, frequent occurrence of Amphistegina radiata at $35 \mathrm{~m}$ in Avarua and of Operculina complanata ammonoides at $65 \mathrm{~m}$ in Avatiu.

\section{COMPARISON WITH OTHER WESTERN PACIFIC ISLAND LOCALITIES}

In a resumé of tropical island faunas of the western Pacific Ocean, Murray (1991) has attempted to group the scattered and inconsistent published benthonic foraminiferal information into eleven larger foraminiferal associations. No information on the Cook Islands microfaunas was available, but the associations were based upon data from neighbouring islands which include Palau (Lessard, 1980; Hallock, 1984); Tobi, Johnston, Mariana and Caroline Islands (Lessard, 1980); Kapingamaringi Atoll (McKee et al., 1959; Lessard, 1980); Oahu, Hawaii (Hallock 1984; Coulbourn \& Resig, 1975); Solomon Islands (Hughes, 1977, 1985); New Caledonia (Lessard, 1980; Debenay, 1985); Tuamotu (Lessard, 1980; Sournia, 1976); Marshall Islands (Cushman et al., 1954); Gilbert Islands (Todd, 1961) and Ryuku Islands, Chichi-Jima and Guam (Matsumaru \& Matsuo, 1976). Foraminifera recovered from the Pacific Ocean (Barker, 1960) and from the Philippines (Graham \& Militante, 1959) proved useful for regional comparison.

The foraminifera recovered from the Cook Island samples are not, however, readily assignable to any of Murray's (1991) associations, although in terms of water depth the Amphistegina lessonii, Amphistegina madagascariensis, Amphistegina radiata or Operculina gaimardii' associations should be expected. Instead, the present study would suggest that a Heterostegina depressa/Borelis schlumbergeri/ Sorites marginalis assemblage could supplement the associations of Murray. It is possible that the rather different character of the foraminiferal associations recovered from north Rarotonga results from the greater degree of open marine influence and higher hydraulic energy within the inter-reef channels. The presence of deeper marine smaller benthonic foraminifera and planktonic species certainly indicate such influence, and this may similarly control the dominance of complex chambered, larger forms such as Borelis and Heterostegina. The predominantly high energy conditions preclude sea-grass development on the back reef areas of the fringing reef, and this is considered probably to influence the microfaunal assemblage, with sea-grass associated forms being generally absent (e.g. Operculina ammonides; Amphistegina radiata at Avarua).

Of interest is the absence of Calcarina and Baculogypsina species but the presence of alveolinids (Borelis schlumbergeri), which is consistent with the distribution of these forms as illustrated by Murray (1991, fig. 13.3); Alveolinella quoii is noticeably absent. Similarly, the absence of Asterorotalia trispinosa is consistent with my own observations; this species is well-represented in Malaysia and Indonesia, as far east as Irian Jaya, but has not been found in the Solomon Islands or other smaller islands of the Western Pacific.

\section{CONCLUSIONS}

In both Avatiu and Avarua channels, the foraminiferal assemblages recovered display a 'background' component of at least 12 species which are presumed to have been, at least partly, derived from the fringing reef which flanks each channel. Up to $14 \mathrm{~m}$ thickness of sediment has been recorded in Avarua channel, the source of which may now be confirmed to be proximal and of coral reef origin.

Despite the consistent presence of the planktonic foraminiferal species Globigerina bulloides at Avatiu, and also within a shallow sample at Avariu, Globigerinoides immaturus is only present deeper than $15 \mathrm{~m}$ at Avarua and $65 \mathrm{~m}$ at Avatiu, with a noteworthy species diversity increase at Avarua channel below $30 \mathrm{~m}$.

Species which display a limited deeper water distribution and which may possibly be in situ, or at least derived from a deeper part of the adjacent reef include Melonis affinis (Avarua, $33 \mathrm{~m}$ ), Cassidulina delicata (Avarua $35 \mathrm{~m}$; Avatiu $48 \mathrm{~m}$ ), Clavulina pacifica (Avatiu, $48 \mathrm{~m}$ ) and Bolivina alata (Avarua, $120 \mathrm{~m}$; Avatiu, $48 \mathrm{~m}$ ).

Future investigation should include a thorough sampling program specifically for foraminiferal research. Such resampling should take place as soon as possible before the sewage disposal project is initiated, so that environmental impact of the sewage on the microfauna may be monitored. Subsequent effects on the reefal fish and crustacean population may significantly impact this source of food for the human inhabitants of north Rarotonga.

\section{ACKNOWLEDGEMENTS}

I wish to thank Mr Cruz Matos, Chief Geologist of the CCOP/SOPAC Technical Secretariat at Suva, Fiji, for providing the samples for this study. The sedimentological report by Dr Gary Gauss (1982), also of CCOP/SOPAC, provided all of the methodology described in this paper. The 
word processing and drafting facilities of the SimonRobertson Group (now Simon Petroleum Technology) and of E. Ross (Saudi Aramco) for the final word processing, are gratefully acknowledged in the preparation of the paper. Suggestions to the original typscript by Drs J.E. Whittaker (British Natural Historv Musuem) and M. Keen (University of Glasgow) have be... needed and have greatly improved the value of the contribution.

\section{Manuscript received July 1993 \\ Manuscript accepted April 1994}

\section{REFERENCES}

Barker, R. W. 1960 . Taxonomic notes on the species figured by $H . B$. Brady in his report on the foraminifera dredged by $H M S$ Challenger during the years 1873-1876. Society of Economic Palaeontologists and Mineralogists, Special Publucations, 9: 238 pp. Tulsa, Oklahoma.

Coulbourn, W. T. \& Resig, J. M. 1975. On the use of benthic foraminifera as sediment tracers in a Hawaiian bay. Pacific Science, 29: 99-115.

Cushman, J. A., Todd, R. \& Post, R. J. 1954. Recent foraminifera of the Marshall Islands. United States Geological Survey Professional Paper 260-H: 319-384.

Debenay, J. P. 1985. Le lagon sud-ouest et la marge insulaire sud de Nouvelle - Caledonje: importance et repartition des foraminiferes de grande taille: Cahiers d'Oceanographie Tropicale, 20: 171-192.

Gauss, G. A. 1982. Sea bed studies in ncarshore areas of Rarotonga, Cook Islands. South Pacific Marine Geology Notes, 2(9): $131-154$

Graham, J. J. and Militante, P. J. 1959. Recent foraminifera from the Puerto Galera area, northern Mindoro, Philippines. Stanford
University Publ. Geol. Sci. 6: $1-170$.

Hallock, P. 1984. Distribution of selected species of living algal symbiont- bearing foraminifera on two Pacific coral reefs. Journal of Foraminferal Research, 14: 250-261.

Hughes, G. W. 1977. Recent foraminifera from the Honiara Bay area, Solomon Islands, Journal of Foraminferal Research, 15: 13-17.

Hughes, G. W. 1985. Recent foraminifera and selected biometrics of Heterostegina from Ontong Java Atoll, Solomon Islands, southwest Pacific. Journal of Foraminferal Research, 15: 13-17.

Keating, E. C. 1978. Atlas of the South Pacific. External Intelligence Bureau, Wellington, New Zealand.

Lessard, R. H. 1980. Distribution patterns of intertidal and shallow-water foraminifera of the tropical Pacific Ocean. Cushman Foundation Special Publications, 19: 40-58.

Lewis, K. B., Utanga, A. T., Hill, P. J. \& Kinga, S. G. 1982. The origin of channel-fill sands and gravels on an algal-dominated reef terrace, Rarotonga, Cook Islands. South Pacific Marine Geology Notes, 2(1): 1-23.

Matsumaru, K. \& Matsuo, Y. 1976. Short note on the benthonic foraminiferids from the beach sediments of the subtropical and tropical islands in the western Pacific region. Journal of Saitama University, Faculty of Education (Mathematics and Natural Science), 25: 15-26.

McKee, E. D., Chronic, J. \& Leopold, E. G. 1959. Sedimentary belts in lagoon of Kapingamargingi Atoll. American Association Petroleum Geololgy Bulletin, 43: 501-562.

Murray, J. W. 1991. Ecology and Palaeoecology of Benthic Foraminifera. Longman Group.

Sournia, A. 1976. Primary production of sands in the lagoon of an atoll and the role of foraminiferan symbionts. Marine Biology, 37: 29-32.

Todd, R. 1961. Foraminifera from Onotoa Atoll, Gilbert Islands. United States Geological Survey Professional Paper, 354-H: $171-191$. 